\title{
Changes of acid value of lipid, chlorogenic acid content and anti-oxidative activities in roasted coffee for short term storage
}

\author{
Jinkyu Lim ${ }^{1,2}$ (D) $\cdot$ Min-Yeol Kim ${ }^{1,2} \cdot$ Sung-Hee Kim ${ }^{1,2} \cdot$ Jin-Sung Ma ${ }^{1,2} \cdot$ \\ Jisun $\mathrm{Oh}^{1,2} \cdot$ Jong Sang Kim ${ }^{1,2}$

\section{단기저장 기간 중 커피원두의 지방산가, chlorogenic acid 및 항산화 활성 변화}

임진규 ${ }^{1,2}$ - 김민열 ${ }^{1,2}$ - 김성희 ${ }^{1,2}$ - 마진성 ${ }^{1,2}$ 오지선 ${ }^{1,2}$ - 김정상 ${ }^{1,2}$

Received: 13 October 2017 / Accepted: 13 November 2017 / Published Online: 31 December 2017

(C) The Korean Society for Applied Biological Chemistry 2017

\begin{abstract}
Regarding the facts that fat, which is easily oxidized, is one of the major responsible factors affecting the quality of aroma, and polyphenol compounds including chlorogenic acid (CGA) contribute the anti-oxidative activities to coffee, we investigated fat oxidation, conversion of CGA, and changes of anti-oxidative activities according to the degree of roasting and storage of 60 days. We found that the amount of extractable fat by diethyl ether is increased as the coffee beans are roasted longer. Furthermore, the acidity values of the fat are increased from $8.91 \pm 0.16$ to $17.81 \pm 0.11$, and $10.37 \pm 0.27$ to $17.93 \pm 0.09$ in the medium and dark roasted coffee beans, respectively, while it is increased from $4.47 \pm 0.11$ to $11.89 \pm 0.18$ in the green coffee bean after 60 days. The CGA contents in the coffee beans were decreased from $310 \pm 8.2$ to $282 \pm 11.2$, then to $58 \pm 0.0 \mathrm{mg}$ in $10 \mathrm{gr}$ of the green, medium and dark beans, respectively, and were not changed significantly during the storage period. However, the anti-
\end{abstract}

Jinkyu Lim $(\bowtie)$

E-mail:jkylim@knu.ac.kr

${ }^{1}$ Major in Food Biomaterials, School of Food Science and Biotechnology, Kyungpook National University, Daegu 41566, Republic of Korea

${ }^{2}$ Institute of Agricultural Science and Technology, Kyungpook National University, Daegu 41566, Republic of Korea

This is an Open Access article distributed under the terms of the Creative Commons Attribution Non-Commercial License (http://creativecommons. org/licenses/by-nc/3.0/) which permits unrestricted non-commercial use, distribution, and reproduction in any medium, provided the original work is properly cited. oxidative activities measured by 2,2-diphenyl-1-picrylhydrazyl and 2,2'-azinobis-(3-ethylbenzothiazoline-6-sulfonic acid radical scavenging assays were not significantly different among the green, medium, and dark coffee beans during the storage period. Furthermore, antioxidant reactive element-luciferase assay showed that biological anti-oxidative activities were increased as coffee beans were more roasted and stored longer. As the total polyphenolic contents in the beans were significantly decreased by roasting, the results suggests that other molecules, such as, Maillard reaction products might play substantial role in antioxidative activity and influence cup quality of coffee.

Keywords Anti-oxidative activity · Antioxidant Response Element-luciferase assay - Chlorogenic acid · Coffee roasting · Lipid oxidation

\section{서 론}

커피는 전 세계적으로 가장 많이 교역이 이루어지는 식품 중의 하나이다. 또한 커피는 세계적으로 가장 널리 많이 섭취되는 음 료로써 polyphenol 화합물을 다량 함유하고 있어서 항산화기능 을 제공하는 대표적인 식품이기도 하다(Charurin 등, 2002; Farah 등, 2008; Stelmach 등, 2015). 커피의 가공상태에 따라 부르는 명칭 중 생두(green coffee bean)는 커피열매의 외피와 속 열매 껍질(parchment), 과육(pulp)이나 점액질(mucilage) 부분 을 세척이나 건조상태로 제거하고 얻은 배유 부분(endosperm) 
을 일컫는다. 커피 생두에서 약리성분을 분리하거나 기능성 식 품 성분을 분리하는 용도(Shimoda 등, 2006; Watanabe 등, 2006) 외에는 커피 생두는 주로 roasting 되어 원두로 가공되고 이로부터 물로 추출한 커피음료들로 소비되게 된다. Roasting 과정을 통하면 생두에서 나는 풀뿌리 냄새나 지린내(peasy smell) 등이 없어지고 대신 커피를 애호하는 사람들이 즐기는 독특한 향, 맛 및 색깔로 변환되게 된다(Czerny 등, 1999).

Roasting의 가공온도와 시간에 따라 커피 생두에 들어있는 성 분들을 변화시키는데 특히 커피 한 컵 $(150 \mathrm{~mL})$ 당 약 $70-350$ $\mathrm{mg}$ 이 들어 있다고 알려진 커피의 polyphenol은 화학적으로 비 교적 안정되게 유지되며 섭취하였을 때 reactive oxygen species 와 reactive carbonyl species (RCS)를 제거해 주는 효능을 갖 고 있음이 여러 연구를 통해 알려져 있다(Klatsky 등, 2006; Nichenametla 등, 2006; Wang과 Ho 2009). 커피 polyphenol 의 주요 형태로 생리활성이 잘 알려진 chlorogenic acid (CGA) (1,3,4,5-Tetrahydroxycyclohexanecarboxylic acid 3-(3,4-dihydroxycinnamate))는 생두 전체 산의 약 $66 \%$ 를 차지하며 생두를 과열 하는 과정에서 epimerization, lactonization, 또는 polymerization 등에 의해 3-Ocaffeoyl- $\gamma$-quinide, 4-O-caffeoyl- $\gamma$-quinide, 5-Ocaffeoyl-epi- $\delta$-quinide, 그리고 3-O-caffeoyl-epi- $\gamma$-quinide chlorogenic acid lactones 의 형태로 변형되며 커피 산미 변화에 영향을 미 친다(Frank 등, 2007; Frank 등, 2008; Moon 등, 2009).

Roasting에서 amino acid와 당이 열에 의해 화학반응을 일으 키는 Maillard 반응으로 갈색으로 변하는 과정들은 그 동안 심 도 있게 연구되어 오면서 약 800 종 이상의 향미성분이 커피 원두와 이로부터 추출한 커피에서 밝혀졌다(Czerny 등, 1996). Maillard 반응물질(Maillard reaction products, MRPs)은 식품의 색, 맛, 감촉, 풍미 등에 영향을 미치는 물질로써 많은 연구자 들에 의해 MRPs가 강한 항산화활성을 갖고 있다는 것이 보고 되었다(Borrelli 등, 2002; Oh 등, 2017).

커피 생두의 열처리 가공에 의해 갈색변화를 일으킨 정도에 따라 가공된 원두를 시나몬, 미디움, 다크 또는 풀시티, 이탈리 안, 프렌치 등으로 나누고 이렇게 가공된 원두가 나타내는 색 도를 이용해 색도계에 의한 분류로 각각 Agtron 65-70 (시나몬), Agtron 55-60 (미디움), Agtron 45-55 (다크), Agtron 35-45 (이 탈리안), Agtron 30-35 (프렌치) 등으로 분류하기도 한다(de Azeredo 2011). 커피의 맛은 열처리가 덜 될수록 신맛이 강하 고 열처리가 더해감에 따라 단맛과 풍미가 깊어지고 열처리가 더해갈수록 커피의 신맛은 사라지고 쓴맛이 점점 더 강해지게 된다. Roasting된 커피는 저장기간이 길수록 점차 풍미가 변화 하여 커피 품질(cup quality)이 낮아지게 된다(Hofmann와 Schieberle 2002). 이는 커피의 풍미성분이 휘발하거나 화학변화 를 일으켜 커피 애호가들이 선호하는 성분들은 줄어들고 다른 성분들이 만들어지면서 일어나는 현상임은 추측할 수 있지만 커 피 성분들의 화학적 변화와 사람이 느끼는 풍미와의 직접적인 상관관계를 정의하기가 어려워 일부 대표적인 풍미성분의 변화 를 분석하여 커피의 전체적 풍미와의 상관관계로 추정하고 있 는 실정이다(Kumazawa와 Masuda 2003).

커피가 원두 상태로 또는 분말상태로 가공되는 순간부터 물 리 화학적 변화가 시작되는데 그 중 지방의 산화는 커피의 풍 미 및 질감에 영향을 미치는 중요한 성분으로 추정되고 있다 (Gichimu 등, 2014). 따라서 본 연구에서는 커피성분의 빠른 변
화를 유도하기 위해 roasting 정도를 달리한 커피 원두를 분쇄 하여 보관하면서 커피 풍미의 변화와 관련이 있을 것으로 추정 하는 커피 지방의 산화를 기간에 따라 산가(acid value) 및 과 산화물가(peroxide value)의 변화를 분석하였고 커피에서 열수로 추출된 물질 중 커피의 항산화활성과 산미에 영향을 주는 CGA 의 변화와 항산화활성을 생화학적 및 세포생물학적으로 분석하 였다.

\section{재료 및 방법}

\section{Coffee 시료 및 커피 추출}

커피 생두 시료는 콜롬비아산 Coffea arabica var. tipica 품종 을 구입하였다. 커피 로스팅 가공은 medium과 dark의 두 수준 으로 진행하였다. Medium을 위해서 반열풍식 로스터(Taehwan, Bucheon, Korea)로 $210{ }^{\circ} \mathrm{C}$ 에서 10 분, dark를 위해서 $210{ }^{\circ} \mathrm{C}$ 에서 15 분 간 roasting하였다. 원두를 분쇄하기 위해 커피분쇄 기(Melitta, Tokyo, Japan)로 갈아서 분말을 밀폐된 용기에 넣어 건조하고 공기가 잘 통하는 $\left(20-25{ }^{\circ} \mathrm{C}\right)$ 암실에 저장하였다.

일정한 조건에서 커피음료를 추출하기 위해서는 분쇄된 $10 \mathrm{~g}$ 의 커피를 beaker에 넣고 $95{ }^{\circ} \mathrm{C}$ 증류수 $50 \mathrm{~mL}$ 를 가하여 2 분간 교반하면서 커피의 성분을 추출하였다. 추출이 끝나면 커피 고 형분을 제거하기 위해 원심분리하여 상층액을 얻었다. 상층액은 액체 크로마토그래피 분석을 위해 $0.45 \mu \mathrm{m}$ membrane filter (Millipore, Merck, Darmstadt, Germany)를 통과시켜서 미세 고 형물을 제거하였다.

\section{지방산의 산화 분석}

조지방의 추출 및 지방의 산가, 과산화물가 측정은 식품공전의 분석법을 따라 시행하였다(Korean Ministry of Food and Drug Safety 2017).

\section{지방의 분석}

미세하게 간 커피분말 $10 \mathrm{~g}$ 을 정확히 달아 무게를 아는 용기에 담아 $100-105{ }^{\circ} \mathrm{C}$ 의 건조기에서 1 시간 건조한 후 데시케이터에 서 식히고 Soxhlet 추출장치에 diethyl ether 로 $60{ }^{\circ} \mathrm{C}$ 에서 8 시 간 추출하였다. 추출이 끝나면 ether를 $50{ }^{\circ} \mathrm{C}$ 에서 증발시키고 $100{ }^{\circ} \mathrm{C}$ 에서 약 1 시간 건조 후 용기의 무게를 달아 용기에 남 아있는 조지방의 무게를 측정하였다.

$$
\text { 조지방 }(\%)=(\text { 추출된 조지방 무게/시료무게 }) \times 100
$$

\section{지방 산가}

지질 $1 \mathrm{~g}$ 을 중화하는데 필요한 $\mathrm{KOH}$ 의 $\mathrm{mg}$ 수 즉 시료 중의 유 리지방산의 양을 구하기 위해 커피 분말에서 hexane으로 실온 에서 추출하고 감압증류기에서 hexane을 분별증류로 제거한 후 얻은 지방시료 $1 \mathrm{~g}$ 을 정밀히 달아 ethanol:ether $(1: 2)$ 혼액 10 $\mathrm{mL}$ 를 넣어 녹였다. 커피 지방시료의 암갈색 때문에 $1 \%$ 티몰프 탈레인/ethanol 용액을 지시약으로 하여 청색이 30 초 간 지속할 때까지 $0.1 \mathrm{M} \mathrm{KOH} /$ ethanol 용액으로 적정했다. 적정에 사용된 $0.1 \mathrm{M} \mathrm{KOH} / \mathrm{ethanol}$ 의 부피(a)에서 바탕적정에 사용된 $0.1 \mathrm{M}$ $\mathrm{KOH} / \mathrm{ethanol}$ 의 부피(b)를 다음의 식을 통해 산가를 계산하였다. 


$$
\text { 산가 }=5.611 \times(\mathrm{a}-\mathrm{b})
$$

\section{지방 과산화물가}

과산화물가, 즉, 유지 $1 \mathrm{~kg}$ 에 의하여 $\mathrm{KI}$ 에서 유리되는 $\mathrm{I} 2$ 의 밀 리당량수 $(\mathrm{meq} / \mathrm{kg})$ 를 측정하기 위해 커피에서 추출한 지방 검체 $1 \mathrm{~g}$ 을 달아 acetic acid:chloroform $(3: 2) 2.5 \mathrm{~mL}$ 에 약간 가온 하여 녹이고 포화 $\mathrm{KI}$ 용액 $0.1 \mathrm{~mL}$ 를 가볍게 흔들어 섞은 다음 어두운 곳에 10 분간 방치하고 물 $3 \mathrm{~mL}$ 를 가하여 세게 흔들어 섞은 다음 전분시액 $0.1 \mathrm{~mL}$ 를 지시약으로 하여 $0.01 \mathrm{M}$ sodium thiosulfate 액으로 적정했다. 적정에 사용된 $0.01 \mathrm{M}$ sodium thiosulfate액의 부피(a)에서 바탕적정에 사용된 $0.01 \mathrm{M}$ sodium thiosulfate액의 부피(b)로부터 다음의 식을 통해 과산화물가를 계산하였다.

$$
\text { 과산화물가 }(\mathrm{meq} / \mathrm{kg})=(\mathrm{a}-\mathrm{b}) \times 10
$$

\section{$\mathrm{CGA}$ 의 정랑}

위의 방법으로 분쇄된 커피원두에서 물로 추출한 커피에 추출 된 $\mathrm{CGA}$ 의 조성 및 $\mathrm{CGA}$ 의 화학적 변화에 의해 형성되는 다 른 다른 성분들을 분석하기 위해 전 처리를 수행하였다. 전 처 리를 위해서 추출된 커피시료 $1 \mathrm{~mL}$ 에 $0.1 \mathrm{M} \mathrm{HCl} / \mathrm{methanol}$ : chloroform $(1: 2) 2 \mathrm{~mL}$ 을 가하고 실온에서 30 분간 흔들어서 섞 어주었다. Chloroform 층을 취하여 원심분리진공건조기에서 말 리고 완전히 건조가 이루어지기 전에 시료를 $0.1 \mathrm{M} \mathrm{HCl} /$ methanol $0.2 \mathrm{~mL}$ 에 녹였다. 액체크로마토그래피 분석을 위해 $\mathrm{C} 18$ column $(4.6 \times 150 \mathrm{~mm}, 5 \mu \mathrm{m})$ 이 연결된 Agilent $1200 \mathrm{LC}$ (Agilent Technologies, Santa Clara, CA, USA)에 시료를 10 $\mu \mathrm{L}$ 주입하고 $40^{\circ} \mathrm{C}$ 를 유지하면서 이동상으로 $10 \mathrm{mM} \mathrm{HCl}$ : methanol $(9: 1)$ 를 $1 \mathrm{~mL} / \mathrm{min}$ 의 유속에서 분리되는 물질들을 $374 \mathrm{~nm}$ 의 파장에서의 흡광도로 측정하였다. CGA의 정량분석을 위해서 CGA 표준품(Sigma-Aldrich, St. Louis, MO, USA)을 $10 \mathrm{mM} \mathrm{HCl}$ :methanol $(9: 1)$ 에 녹여서 측정하여 $\mathrm{CGA}$ 의 retention time과 표준곡선을 얻었다.

\section{항산화활성의 측정}

$\mathrm{DPPH}$ radical 소거능 활성을 측정하기 위해 Kang 등(2016)의 방법과 Katsube 등(2004)의 방법을 시료 특성에 맞춰 실시하였 다. 커피 추출물을 탈이온수로 연속 희석하여 각 희석농도에서 $50 \mu \mathrm{L}$ 씩을 취하여 96-well plate에 넣었다. 여기에 2,2-diphenyl1-picrylhydrazyl (DPPH) $/ 50 \%$ 에탄올 $200 \mu \mathrm{L}$ 를 넣고 30 분간 실온에서 반응하였다. $550 \mathrm{~nm}$ 에서의 흡광도 변화를 측정하기 위 해 Multilabel Counter (PerkinElmer, Inc., Wellesley, MA, USA)를 사용하였다. Radical 소거활성을 계산하기 위해 사용한 식이다. Radical 소거활성 $(\%)=100 \times(\mathrm{A}-\mathrm{B}) / \mathrm{A}$, 여기서 $\mathrm{A}$ 는 control (시료 없이 측정한 $\mathrm{DPPH}$ radicals의 흡광도) 그리고 $\mathrm{B}$ 는 시료 와 반응한 후 radicals의 흡광도이다. 각 시료의 항산화활성 결 과는 3 반복 실험결과의 평균 $\pm \mathrm{SD}$.로 표시하였다.

$\mathrm{ABTS}^{++}$radical 소거능 분석을 위해 먼저 2,2-azino-bis(3ethylbenzothiazoline-6-sulphonic acid) (ABTS) 용액을 만들기 위해 $5 \mathrm{~mL} 7 \mathrm{mM} \mathrm{ABTS} / \mathrm{dH}_{2} \mathrm{O}$ 과 $80 \mu \mathrm{L} 2.45 \mathrm{mM}$ potassium persulfate를 함께 넣고 빛을 차단한 상태로 실온에서 12시간 반 응하여 ABTS radical cation $\left(\mathrm{ABTS}^{*+}\right)$ 을 얻었다( $\operatorname{Re}$ 등, 1999).
반응 후 용액의 $734 \mathrm{~nm}$ 에서의 흡광도가 0.7 이 되도록 ethanol 로 희석하였다. $\mathrm{ABTS}^{++} 1 \mathrm{~mL}$ 를 $50 \mu \mathrm{L}$ 의 시료가 들어 있는 유 리 튜브에 넣고 30 초간 vortex 하였다. 5분 더 반응 시킨 후 흡광도를 $734 \mathrm{~nm}$ 에서 측정하였다. Radical 소거능 활성도는 시 료가 없는 상태에서 측정한 값과 비교하여 변화된 흡광도의 백 분율로 계산하였다. 모든 실험에서 각 시료는 3 반복을 하여 측 정하였다.

Antioxidant Response Element (ARE) 활성 분석을 위해 사람 의 간세포주인 HepG2에 Antioxidant Response Element (ARE)luciferase/pGL vector로 transfection하여 얻은 HepG2-ARE cell (Woo 등, 2017)을 사용하여 luciferase reporter 분석을 진행하였 다. 분석을 위하여 먼저 6-well plate에서 sub-confluent하게 된 $\mathrm{HepG} 2-\mathrm{ARE}$ 세포를 $0.5 \% \mathrm{FBS}$ 조건에서 12시간 동안 serum starvation을 시킨 후 시료를 100 및 $500 \mu \mathrm{g} / \mathrm{mL}$ 의 농도로 12 시간 처리하였다. Luciferase activity를 측정하기 위해 Promega 사의 luciferase assay kit을 사용하였으며 실험 방법은 kit의 설 명서를 따랐다. 즉, 세포를 $3 \mathrm{~mL}$ ice cold PBS로 2회 세척한 후 lysis buffer로 세포를 녹여 세포 추출액을 얻고 이 추출액 $10 \mu \mathrm{L}$ 를 luciferase 기질용액과 석은 후 TD-20/20 luminometer (Turner Designs, Sunnyvale, CA, USA)로 활성을 측정하였다. 각 측정 값들은 bicinchoninic acid protein assay (Pierce Biotech., Waltham, MA, USA) 방법으로 측정된 단백질 농도를 기준으로 보정하였으며 보정된 값들은 다시 음성대조구로 사용된 vector control에서 얻은 값을 1로 하였을 때 몇 배 증가하였는지 배수 로 계산하였으며 양성 대조군으로 $5 \mu \mathrm{M}$ Sulforaphane (SigmaAldrich)의 luciferase 활성값을 기준으로 다시 보정하였다. 각 결 과는 시료당 3 회 반복하여 측정한 값 $\pm \mathrm{SD}$.로 표시하였다.

커피 추출물의 총 페놀 함량(total polyphenolic content, TPC) 측정을 위해 각 커피 추출물의 총 페놀함량은 Folin-Ciocalteu 시약으로 측정하였다(Kuhnen 등, 2014). 분석을 위해 1:10으로 희석된 시료 $100 \mu \mathrm{L}$ 를 tube에 넣고 여기에 탈이온수에 1:5로 희 석한 Folin-Ciocalteu 시약 $15 \mu \mathrm{L}$ 를 넣고 섞은 후 실온에서 5 분 간 반응시켰다. 이어서 $50 \mu \mathrm{L} \quad 10 \% \mathrm{w} / \mathrm{v}$ sodium bicarbonate 용액과 넣어주고 섞은 후 어두운 실온에서 5 분간 반응 후 반 응물을 96-well 평판으로 흡광도의 변화를 microplate reader로 $593 \mathrm{~nm}$ 에서 측정하였다. 바탕용액으로는 시료를 제외하고 위의 모든 용액이 들어간 것을 사용하였다. $\mathrm{TPC}$ 의 정량을 위해 gallic acid를 이용한 표준곡선을 얻었으며 이 곡선에서 시료 $\mathrm{mL}$ 당 $\mathrm{TPC}$ 의 양을 $\mu \mathrm{g}$ gallic acid의 양으로 환산하였다.

\section{결과 및 고찰}

\section{저장기간 동안 커피의 지방의 산화}

일반적으로 roast된 원두나 이를 분쇄 가공한 분말커피의 경우 저장기간이 길어질수록 커피의 풍미가 변화하여 커피의 품질 (cup quality)이 떨어진다. 커피의 풍미변화와 연관된 변화 중 지 방의 산화에 의한 이취(rancidity)가 가장 중요한 요인들 중의 하나로 추정하고(Vila 등, 2005; Smith 등, 2004) 추출 가능한 지방함량, 지방의 산가 및 과산화물가 변화를 분석하였다. 커피 콩에서 diethyl ether에 의해 추출되는 지방의 함량은 3 반복 실 험에서 콜롬비아 커피 생두의 경우 $10.84 \pm 0.12 \%$, medium roast 
Table 1. Lipid contents in the roasted Coffea arabica var. tipica extracted by diethyl ether

\begin{tabular}{ccc}
\hline \hline Green bean & Medium roast & Dark roast \\
\hline $10.84 \pm 0.12 \%$ & $14.09 \pm 0.07 \%$ & $17.37 \pm 0.03 \%$ \\
\hline
\end{tabular}

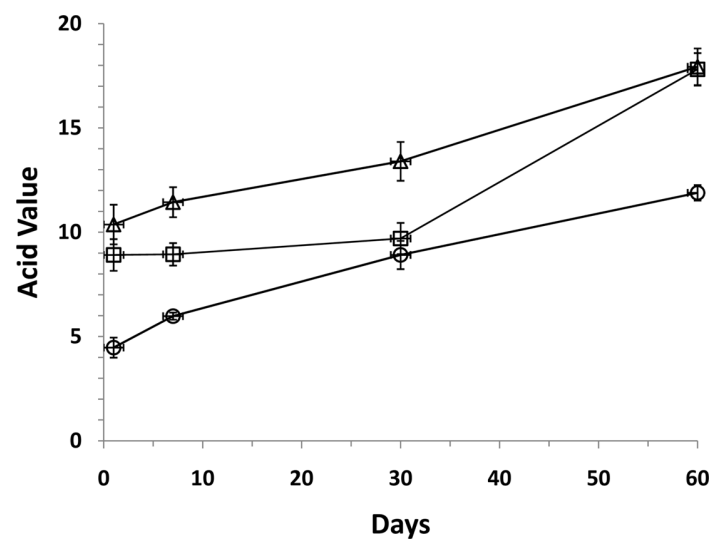

Fig. 1 Changes of acidity values of lipid of the powdered coffee beans roasted at different levels during storage at RT. Green coffee bean $(\bigcirc)$, medium roast coffee bean $(\square)$, dark roast coffee bean $(\triangle)$ were powdered and stored at room temperature up to 60 days before analyzed

원두와 dark roast 원두는 각각 $14.09 \pm 0.07 \%, 17.37 \pm 0.03 \%$ 의 추출 가능한 지방함량을 나타냈다(Table 1). 이러한 현상은 커 피 콩의 내부에 존재하는 지방이 열처리 과정을 통해 커피콩의 조직이 파손되어 roasting이 오래 지속될수록 커피 원두 표면에 기름막이 형성되는 현상을 보이는 것과도 관련이 있다. 따라서 roasting이 더 많이 된 원두일수록 열수에 의해서도 지방의 추 출이 더 많아 질 수 있음을 의미하는 결과이다.

커피 원두로부터 추출가능 지방 함량과 커피의 기호도와는 양의 상관관계를 갖고 있는 것이 보고되어 있고(Gichimu 등, 2014), 일반적으로 Coffea arabica에는 평균 $15 \%$ 의 지방함량과 Coffea canephora (Robusta)에는 평균 $10 \%$ 의 지방함량의 차이 가 커피의 기호도에 영향을 미치고 있음을 알 수 있다. 본 실 험에서 Arabica 커피의 건조무게의 약 $17 \%$ 정도를 차지하는 지 방의 산화에 의한 변화는 커피의 풍미에 중대한 영향을 미칠 수 있음을 예측할 수 있다. 특히 roast 된 원두에는 열처리 과 정 중에 생성된 산화물질 등이 저장기간 동안 배출되는 과정에 서 지방의 산화에 영향을 미칠 수 있다. 따라서 본 연구에서는 저장기간 동안 커피의 $14-17 \%$ 정도를 차지하는 지방의(Table 1) 산화가 커피의 풍미변화에 영향을 미칠 수 있다는 가설을 세 우고 분쇄된 생두와 roast된 커피 가루에서 추출한 지방의 유리 지방산의 변화와 과산화물가를 측정하였다. Roasting 가공 직전 의 콜롬비아 생두(Coffea arabica) 커피분말의 산가는 $4.47 \pm 0.11$ 이었으나 저장기간 동안 점차 증가하여 60 일간의 저장 후에는 $11.89 \pm 0.18$ 을 나타내어 분쇄된 생두 분말의 경우는 지방의 산 가가 지속적으로 증가함을 보였다. Medium roast 원두 커피분 말의 경우 가공 당시에는 $8.91 \pm 0.16$ 으로 roasting에 의해 산가 가 생두에서 보다2배정도 증가함을 보였고 저장기간 초기 30 일 간은 산가의 유의적인 변화를 보이지 않다가 60 일 후에는 $17.81 \pm 0.11$ 로 dark roast 원두커피분말에서의 $17.93 \pm 0.09$ 와 유사
한 수준의 산가를 보였다. Dark roast 원두의 커피분말은 가공 시점의 산가인 $10.37 \pm 0.27$ 에서 저장기간 동안 지속적으로 증가 를 보였다(Fig. 1). 커피 생두에서는 지방 산가의 변화가 거의 없다고 알려져 있으며 18 개월 간의 저장기간 동안에도 산가는 1.9 에서 2.3 정도 밖에 변화하지 않음이 보고되어 있다(Speer 와 Kölling-Speer 2006). 그러나 생두나 생두를 roasting 가공한 원두를 분쇄한 상태로 60 일간 실온에서 저장한 경우 생두 분쇄 물에서도 산가의 변화가 $4.47 \pm 0.11$ 에서 $11.89 \pm 0.18$ 로 증가하여 커피콩을 분쇄하면 빠르고 지속적으로 산화가 이루어 짐을 알 수 있었고 열처리 시간이 긴 dark 원두는 medium원두에 비해 산가가 지속적으로 증가함을 알 수 있었다. 이는 열처리 시간 이 길수록 커피 원두의 표면에 지방이 더 많이 노출되어(Toci 등, 2013) 지방의 산가를 증가시키는 것으로 판단된다.

지방의 과산화물가는 생두, medium 원두, dark 원두에서 60 일 간의 저장기간 동안 모두 바탕적정 수준으로 나타났다(결과 미제시). 이는 커피성분 중의 항산화물질에 의해 과산화물가 적 정이 저해된 것으로 추정된다.

\section{커피 roasting 조건과 저장기간 동안의 CGA 변화}

이미 여러 연구에서 보고된 바와 같이 생두를 roasting하는 과 정에서 커피의 polyphenol 성분들이 산화 또는 탈수반응에 의 해 감소한다고 알려졌다(Farah 등, 2005; Perrone 등, 2008). 본 연구에서는 roasting정도에 따라 원두에서 추출되는 $\mathrm{CGA}$ 의 변 화와 또한 60 일의 저장기간 동안 일어나는 $\mathrm{CGA}$ 의 변화 등을 분석하기 위해 커피원두를 분쇄기로 갈아서 실온에서 저장하면 서 $10 \mathrm{~g}$ 의 커피를 사용하여 $50 \mathrm{~mL}$ 의 $95{ }^{\circ} \mathrm{C}$ 증류수로 추출하 여 만든 커피에 존재하는 $\mathrm{CGA}$ 를 3 회 반복하여 분석하였다(Fig. 2와 Table 2). 커피 생두 분말로부터 추출한 커피에는 총 310 $\mathrm{mg}$ 의 CGA가 분석되었다. 같은 방법으로 medium 커피원두에 서 분석된 $\mathrm{CGA}$ 함량은 retention time 기준 32.9 분 근처에서 용리되는 peak 면적을 비교할 때 $280 \mathrm{mg}$ 정도로 생두에 비해 약 $10 \%$ 정도 감소한 것으로 나타났으나 $210{ }^{\circ} \mathrm{C}$ 에서 10 분 roasting 해서 얻은 medium roast보다 $210^{\circ} \mathrm{C}$ 에서 15 분 가열한 dark 커 피의 경우는 $\mathrm{CGA}$ 의 함량은 급격하게 감소하여 생두의 $\mathrm{CGA}$ 함 량의 $2 \%$ 정도인 $5.8 \mathrm{mg}$ 을 유지하였다. 흥미롭게도 생두에서 추 출되는 물질 중 액체 크로마토그라피에서 13.15 분과 41.63 분에 나타나는 peak들의 비율은 생두와 비교해 medium 원두에서 70 및 $50 \mathrm{mg}$ 으로 각각 증가하였으나 dark 원두에서는 0.12 및 0 $\mathrm{mg}$ 으로 대폭 감소하였다. 이러한 현상은 CGA가 열에 의해 탈 수반응 결과 만들어지는 chlorogenic acid lactones들이나 CGA 동일분자 내에서 일어나는 transesterification 반응에 의해 만들 어지는 $\mathrm{CGA}$ 의 이성질체들일 가능성과(Farah 등, 2005) 커피 내 다른 성분들이 $\mathrm{CGA}$ 의 용리조건에서 추출되는 가능성을 예상 할 수 있다. 한편, 커피콩의 roasting이 지속되어 dark roast로 가면 medium roast에서 증가하였던 $\mathrm{CGA}$ 의 이성질체나 lactone 들로 추정되는 물질들의 양이 $\mathrm{CGA}$ 와 함께 급격히 감소하였다 (Fig. 2).

가공된 커피 원두의 저장기간 동안 $\mathrm{CGA}$ 의 변화를 분석하기 위해 커피원두를 분쇄기로 갈아서 실온에서 60 일 간 저장하면 서 $10 \mathrm{~g}$ 의 커피를 사용하여 $50 \mathrm{~mL}$ 의 $95^{\circ} \mathrm{C}$ 증류수로 추출하여 만든 커피에 존재하는 $\mathrm{CGA}$ 를 분리하는 조건의 액체 크로마토 그라피에 의해 얻어진 크로마토그램에 의하면 CGA는 medium 

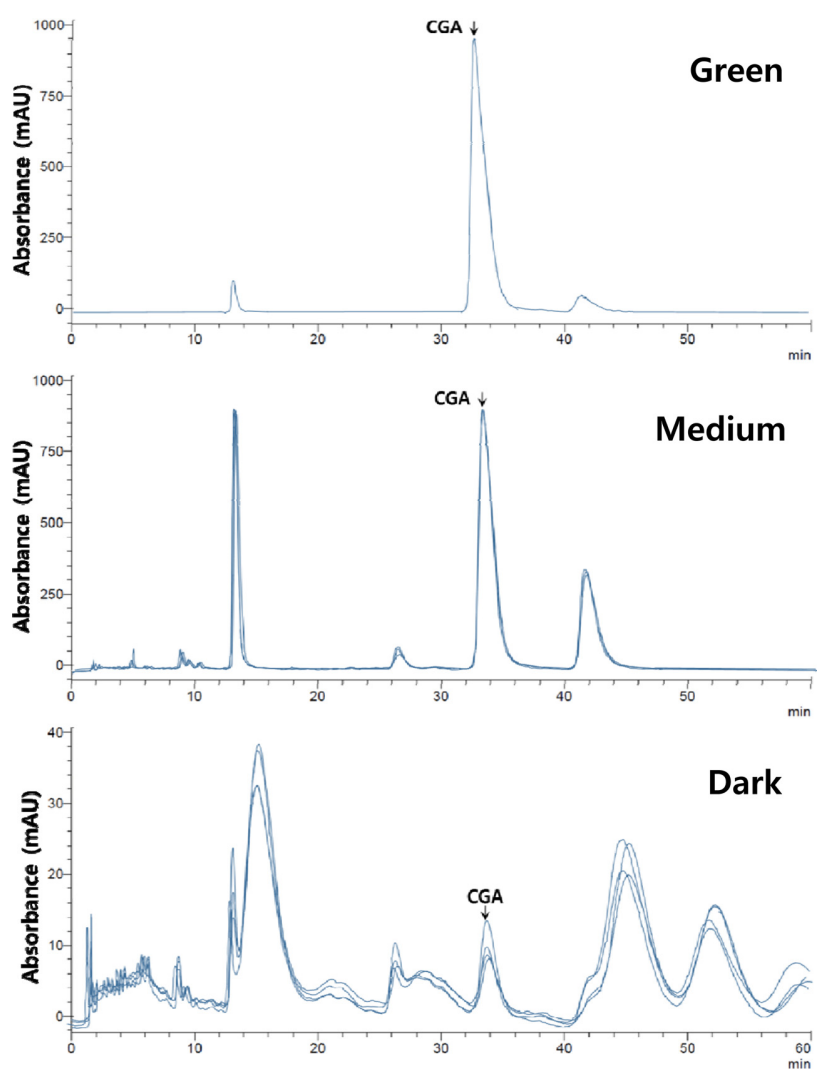

Fig. 2 CGA extracted from the brewed coffees were separated by a C18 column. Chromatograms of 1, 7, 30 and 60-day samples of the medium roast (Medium) and dark roast (Dark) coffee bean are superimposed to show the changes of CGA (indicated with an arrow) concentration during the roasting process and storage. The chromatogram of CGA from the green coffee bean (Green) representing $100 \%$ of CGA from coffee bean is shown on top of the figure

roast나 dark roast에서 60 일 간의 저장기간 동안 변화 없이 처 음 가공되었을 때의 농도를 유지하였으며 크로마토그램 역시 저 장기간 동안 변화 없이 유지되었다(Fig. 2).

\section{커피 원두의 Roasting에 따른 항산화활성의 변화}

커피 추출물의 항산화 활성을 $\mathrm{DPPH}$ 와 $\mathrm{ABTS}^{+\bullet}$ radicals 소거 능으로 측정하였다. 커피추출물 $0.1,0.2,0.39,0.78,1.56$, 3.13 , 및 $6.25 \%(\mathrm{v} / \mathrm{v})$ 에 대한 radical 소거능은 $\mathrm{DPPH}$ 분석에서 는 생두에서 다른 시료와 비교할 때 유의적으로 $24 \%$ 정도 낮은 $0.33 \%(\mathrm{v} / \mathrm{v})$ 의 EC50값을 나타냈고 다른 원두에서는 roasting 조 건이나 저장기간과 상관 없이 유사한 $0.41-0.44 \%(\mathrm{v} / \mathrm{v})$ 의 EC50
Table 2 Changes of CGA concentration in coffee brewed from differently roasted coffee beans

\begin{tabular}{lcc}
\hline \hline & Coffee Bean & $\mathrm{CGA}^{\mathrm{a}}$ \\
\hline Green & & $310.1 \pm 8.2$ \\
Medium & & \\
& 1-day & $282.4 \pm 11.2$ \\
& 7-day & $252.9 \pm 7.5$ \\
& 30-day & $252.8 \pm 12.4$ \\
& 60-day & $280.4 \pm 9.7$ \\
Dark & & \\
& 1-day & $5.9 \pm 0.23$ \\
& 7-day & $5.5 \pm 0.18$ \\
& 30-day & $7.9 \pm 0.56$ \\
& 60-day & $6.2 \pm 0.32$ \\
\hline
\end{tabular}

${ }^{\mathrm{a}} \mathrm{CGA}$ concentration in $\mathrm{mg} / 50 \mathrm{~mL}$ of brewed coffee from $10 \mathrm{~g}$ of coffee bean

를 보였다(Fig. 3A). 그러나 Fig. 3B에서 보는 바와 같이 $\mathrm{ABTS}^{+\bullet}$ radical 소거능은 생두, 각 roasting 조건의 원두, 그리 고 저장 기간과 상관 없이 유사하게 나타났다. 이 결과들로 미 루어 볼 때 항산화물질들은 로스팅 조건이나 저장기간에 큰 영 향을 받지 않고 대체로 유지되는 것으로 판단된다.

세포 수준에서 생두, medium, dark 커피추출물의 항산화활성 을 측정하기 위해 $\mathrm{ARE}$ 에 luciferase 유전자가 연결된 reporter assay system이 안정적으로 유지되는 HepG2 cell에 각 추출물 들을 건량기준 100 또는 $500 \mu \mathrm{g} / \mathrm{mL}$ 되도록 배지에 처리하고 12 시간 후에 luciferase 효소의 활성을 측정하였다. Fig. 4에서 볼 수 있듯이 항산화활성에 의한 luciferase의 발현은 roasting이 더 진행될수록 저장 기간이 길어질수록 농도의존적으로 높게 나타 났다. 이 결과는 앞의 $\mathrm{DPPH}$ 와 $\mathrm{ABTS}^{\circ+}$ radical 소거능 분석 결 과와는 반대되는 결과이기 때문에 이를 입증할 연구를 진행하 고 있지만 현재로서는 이에 대한 설명으로 Maillard reaction에 의해 생성되는 커피의 melanoidin들이 영향을 미쳤을 가능성을 생각할 수 있으며, 이들 물질이 coffee bean의 roasting 이 길어 질수록, 그리고 저장 기간 동안 원두에 더 많이 생성되거나 저 장기간이 경과할수록 지방과 함께 항산화물질이 열수에 의해 더 잘 추출되어 항산화활성이 증가되는 현상을 나타냈을 것으로 예 상된다.

Roasting 정도와 저장기간에 따른 $\mathrm{DPPH} / \mathrm{ABTS}^{+\bullet}$ radicals 소 거능 활성이 유지되는 현상과, ARE-Luciferase유도 활성은 오 히려 증가하는 현상에 대한 이유를 밝히기 위해 커피 추출물에 존재하는 총 페놀화합물의 농도를 측정하였다. 커피 원두에서 열수로 추출된 총 페놀화합물 함량은 생두와 비교할 때 roasting

Table 3. EC50 values of coffee extracts by ABTS and DPPH scavenging assays

\begin{tabular}{cccccc}
\hline \hline & \multicolumn{5}{c}{ EC50 } \\
\cline { 2 - 6 } & Green & Medium & Medium $(60)^{1}$ & Dark & Dark $(60)^{1}$ \\
\hline ABTS & $0.37 \pm 0.14^{\mathrm{a}}$ & $0.32 \pm 0.015^{\mathrm{a}}$ & $0.33 \pm 0.017^{\mathrm{a}}$ & $0.32 \pm 0.026^{\mathrm{a}}$ & $0.32 \pm 0.032^{\mathrm{a}}$ \\
DPPH & $0.33 \pm 0.02^{\mathrm{b}}$ & $0.44 \pm 0.13^{\mathrm{c}}$ & $0.45 \pm 0.006^{\mathrm{c}}$ & $0.42 \pm 0.023^{\mathrm{c}}$ & $0.41 \pm 0.01^{\mathrm{c}}$ \\
\hline
\end{tabular}

\footnotetext{
${ }^{\mathrm{b}}$ statistically significant with $p<0.05$

a, c no significant difference among samples

${ }^{1} 60$ days after storing
} 

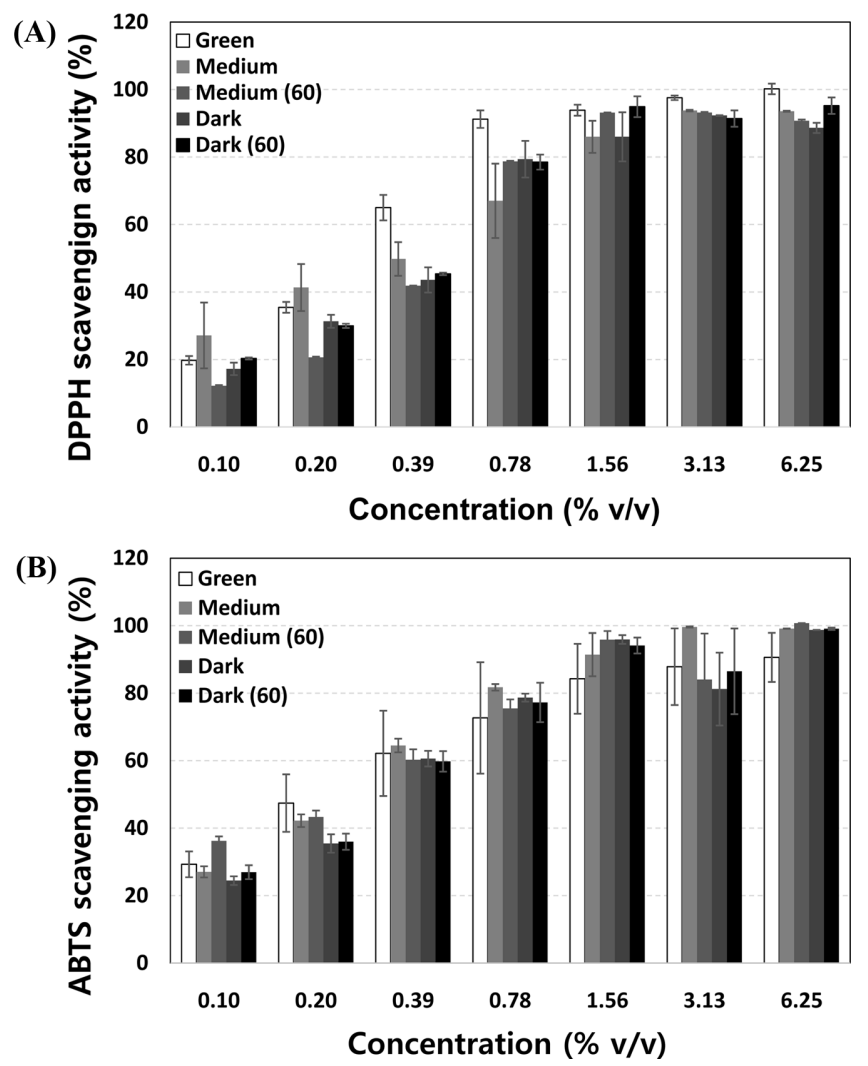

Fig. 3 Anti-oxidative activities of the coffee extracts. (A) DPPH radical scavenging activity, and (B) $\mathrm{ABTS}^{+}$radical scavenging activity. Results are expressed as percentage mean $\pm S D(n=3)$. Coffee extracts from green bean (Green), medium and dark roasted beans were freeze dried and dissolved as 50 -fold concentrated to make 0.1 to $6.25 \%(\mathrm{v} / \mathrm{v})$ solution in the cell culture media. Roasted beans stored for 60 days are designated as Medium (60) and Dark (60), respectively

이 진행됨에 따라 생두와 medium을 비교하면 $12 \%$ 가 감소했으 나 생두와 dark를 비교할 때 $43 \%$ 감소한 양을 나타냈다. 이러 한 변화는 커피 생두의 roasting과정에서 열처리 시간이 길어질 수록 총 페놀화합물의 감소가 급격히 나타남을 알 수 있다. 그 러나 60 일의 저장기간 동안 생두, medium, dark간에는 유의적 인 차이를 보이지 않았다(Fig. 5).

커피 콩의 roasting 가공 중 항산화활성을 보일 것으로 알려 진 총 polyphenol의 감소에도 불구하고 $\mathrm{DPPH}$ 그리고 $\mathrm{ABTS}^{+*}$ radical 소거능 활성 분석에서는 생두 외에는 통계적으로 유의 성 있는 차이를 보이지 않았기 때문에 커피 추출물에는 polyphenol외에도 항산화활성을 갖는 물질이 roasting이 진행됨 에 따라 그리고 저장이 진행됨에 따라 오히려 더 생성된다고 추측할 수 있고 이러한 조건을 충족하는 물질로는 MRPs가 유 력하다.

식품가공 중에 아미노산과 당이 반응하여 생성되는 MRPs가 매우 강력한 항산화활성을 갖고 있음은 잘 알려져 있다(Borelli et al. 2002; Dittrich 등, 2003; Samaras 등, 2005; van Boekel 등, 2010). 산분해저항성이 있는 MRPs 고분자의 melanoidin 화 합물들은 biosystem에서도 항산화활성을 갖고 있으며(Papetti 등, 2006), 또한 HepG2 세포에 melanoidin을 처리한 결과 세포 내

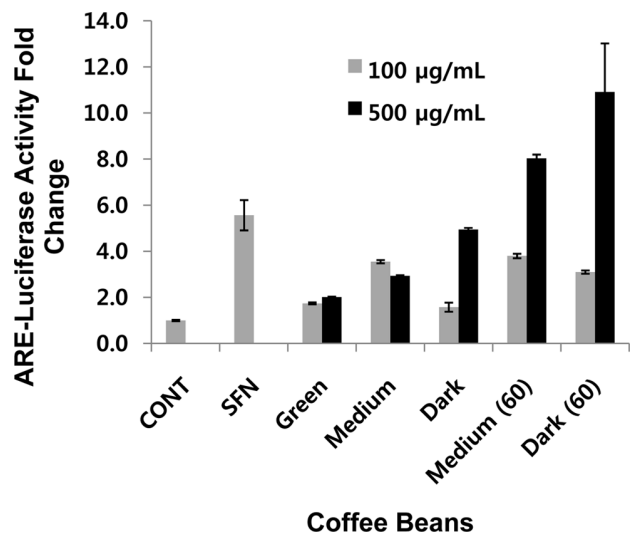

Fig. 4 Induction of antioxidant response element (ARE)-luciferase activity by the coffee extract treatment at concentrations of 100 and 500 $\mu \mathrm{M} / \mathrm{mL}$ on HepG2 cells stably transfected with ARE-luciferase reporter vector for $12 \mathrm{~h}$. The normalization of the luciferase activity was performed on the basis of protein concentrations extracted from the cells. The data were collected from triplicated samples and expressed as the induction fold changes relative to that of the vehicle vector control. Roasted beans stored for 60 days are designated as Medium (60) and Dark (60), respectively. Sulforaphane (SFN) was used as a positive control to monitor the assay system

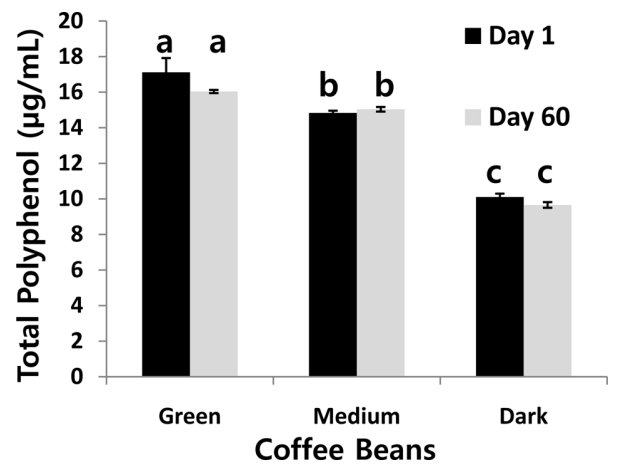

Fig. 5 Changes of total polyphenol contents in coffee beans by roasting and storage. TPC extracted from 10 grams of the green, medium and dark beans in $50 \mathrm{~mL}$ of distilled water are presented as equivalent amount of gallic acid. TCP contents in the beans were not significantly changed during the storage period of 60 days. The statistical differences $(p<0.05)$ of the TPC contents are designated with different letters, a, b and $c$, on the graph bars. Same letter designates no significant difference

환원된 glutathione의 수준이 증가하여 세포를 산화적 스트레스 로부터 보호하는 효과가 보고되었다(Goya 등, 2007; Martin 등, 2009). 이 결과들은 MRPs가 세포에서 항산화 효소계를 유도하 는 transcription factor인 Nrf2를 핵으로 이동하게 함으로써 macrophage나 장벽세포인 $\mathrm{CaCo}-2$ 세포의 항산화활성을 높이는 것이 알려짐으로 분자수준에서 더 확인되었다(Xue 등, 2008; Sauer 등, 2013).

최근의 연구에서는 MRPs을 분획하여 시험 쥐에 80 일간 급 여한 결과 분변에서 장벽의 항-염증반응에 중요역할을 하는 propionic acid가 5배 이상 증가한 것을 관찰하였다. 이 결과는 $\mathrm{MRPs}$ 가 장 내의 세균총 변화에 영향을 미치고 그 결과 단사 슬지방산(SCFA) 생성에 영향을 미쳐서 항염증 효능을 나타낼 
수 있음을 의미한다(Delgado-Andrade 등, 2017).

열처리 가공은 커피에 존재하는 여러 물질들을 변화시키거나 결합시켜 다양한 물질들을 생성하게 되어 열처리 가공에 따라 다른 커피 풍미를 나타내게 되는데, 본 연구에서 보이듯이 medium이나 dark원두에서 제조한 커피의 열수 추출 가능한 지 방함량, 지방의 산화, $\mathrm{CGA}$ 의 산화나 항산화활성 등의 저장기 간 동안의 변화상태에 관한 결과들은 커피의 풍미나 품질을 이 해하는데 중요한 단서를 제공할 수 있다. 또한 이들 물질과 커 피의 다른 성분들, 예를 들면 아미노산, 단백질, 탄수화물, 등과 결합하여 커피의 향이나 입 안에서의 촉감에 변화를 일으킨다 고 추정하고 있으나 그에 대한 화학변화들이 너무 복잡하고 다 양하여 커피 향을 결정하는 구체적인 기작은 더 심도 있게 연 구되어야 한다. 그리고 본 연구의 결과들을 종합해 볼 때 커피 의 항산화물질은 polyphenol류 외에 다른 물질, 예를 들면, MRPs 등도 항산화활성에 관여할 수 있고 커피 가공 및 저장 기간 동안 커피 음료의 풍미에도 영향을 미치게 됨을 알 수 있 다. 커피음료를 섭취하였을 때 polyphenol 류나 MRPs 등의 항 산화물질이 장벽세포에 항산화활성을 유도하거나 장 내 미생물 의 균총 변화와 대사체 생성에 영향을 미치는 과정을 통해 신 체에 항산화 및 항염증반응을 조절하는 데 대한 체계적인 연구 를 통해 그 동안 많은 연구자에 의해 보고된 커피 음료의 건강 에 유익한 효과에 대한 생리적 메카니즘을 확인할 필요가 있다.

\section{초 록}

쉽게 산화되는 지방이 커피의 풍미에 중요한 영향을 미치는 주 요 요소 중 하나라는 것과 chlorogenic acid (CGA)가 커피의 주요 항산화 물질이라는 점을 고려하여 본 연구에서는 커피생 두의 열처리 가공 정도와 단기저장 기간에 따라 변화하는 지방 의 산화와 $\mathrm{CGA}$ 의 농도변화와 동시에 항산화활성을 분석하였 다. 커피 원두를 얻기 위한 열처리 가공 시간이 길수록 diethyl ether로 추출되는 지방의 양이 증가하였으며 지방의 산가는 분 쇄된 medium과 dark 커피에서 가공 첫날 $8.91 \pm 0.16$ 과 $10.37 \pm 0.27$ 를 각각 보이다가 60 일 간의 저장기간 후에는 $17.81 \pm 0.11$ 과 $17.93 \pm 0.09$ 로 증가하였으나 분쇄 생두에서는 $4.47 \pm 0.11$ 로부터 $11.89 \pm 0.18$ 로 증가함을 보였다. CGA 함량은 $10 \mathrm{~g}$ 커피를 이용 하여 커피를 제조할 경우 생두, medium, dark 커피의 경우 각 각 $310 \pm 8.2,282 \pm 11.2,5.9 \pm 0.23 \mathrm{mg}$ 을 나타내었으며 이들 농도 는 60 일간의 저장 기간 동안 변화되지 않고 유지되었을 뿐 아 니라 $\mathrm{CGA}$ 를 분리하는 액체 크로마토그래피 조건에서 얻어지 는 용리 크로마토그램도 저장기간 동안 변화되지 않고 유지되 어 $\mathrm{CGA}$ 가 저장기간 동안 다른 물질로 변화되지 않음을 보였 다. 2,2-diphenyl-1-picrylhydrazyl와 2,2'-azinobis-(3-ethylbenzothiazoline-6-sulfonic acid radical 소거능 분석에서 원두 간 그리고 저장기간에 따른 특이적인 변화를 보이지 않았으며 AREluciferase 활성 분석에서는 오히려 roasting이 진행될수록 저장 기간이 오랠수록 항산화활성이 증가함을 보였고 총 polyphenol 의 함량은 roasting가공이 진행됨에 따라 감소함을 보였기 때문 에 커피의 항산화활성은 polyphenol 외에 다른 물질, 즉, melanoidin과 같은 물질이 생성되어 항산화활성을 높이고 커피 풍미에도 영향을 미칠 가능성을 보였다.
Keywords 지방산화 · 커피 볶음 - 클로로겐산 - 항산화물질반 응_루시퍼라제 분석 · 항산화활성

\section{References}

Borelli RC, Visconti A, Mennella C, Anese M, Fogliano V (2002) Chemical characterization and antioxidant properties of coffee melanoidins. J Agric Food Chem 50: 6527-6533

Charurin P, Ames JM, del Castillo MD (2002) Antioxidant activity of coffee model systems. J Agric Food Chem 50: 3751-3756

Czerny M, Mayer F, Grosch W (1996) Detection of odor-active ethenylalkylpyrazines in roasted coffee. J Agric Food Chem 44: 3268 3272

Czerny M, Mayer F, Grosch W (1999) Sensory study on the character impact odorants of roasted Arabica coffee. J Agric Food Chem 47: 695-699

de Azeredo AMC (2011) Coffee roasting: color and aroma-active sulfur compounds. Disseration, University of Florida

Delgado-Andrade C, de la Cueva SP, Jesús Peinado MJ, Rufián-Henares JA, Navarro MP, Rubio LA (2017) Modifications in bacterial groups and short chain fatty acid production in the gut of healthy adult rats after long-term consumption of dietary Maillard reaction products. Food Res Int 100: 134-142

Dittrich R, El-Massry F, Kunz K, Rinaldi F, Peich CC, Beckmann MW, Pischetsrieder M (2003) Maillard reaction products inhibit oxidation of human low-density lipoproteins in vitro. J Agric Food Chem 51: 3900 3904

Farah A, De Paulis T, Trugo LC, Martin PR (2005) Effect of roasting on the formation of chlorogenic acid lactones in coffee. J Agric Food Chem 53: 1505-1513

Farah A, Monteiro M, Donangelo CM, Lafay S (2008) Chlorogenic acids from green coffee extract are highly bioavailable in humans. J Nutri 138: 2309-2315

Frank O, Blumberg S, Krumpel G, Hofmann T (2008) Structure determination of 3-O-caffeoyl-epi- $\gamma$-quinide, an orphan bitter lactone in roasted coffee. J Agric Food Chem 56: 9581-9585

Frank O, Blumberg S, Kunert C, Zehentbauer G, Hofmann T (2007) Structure determination and sensory analysis of bitter-tasting 4-vinylcatechol oligomers and their identification in roasted coffee by means of LC-MS/ MS. J Agric Food Chem 55: 1945-1954

Gichimu BM, Gichuru EK, Mamati GE, Nyende AB (2014) Biochemical composition within Coffea arabica cv. Ruiru 11 and its relationship with cup quality. J Food Res 3: 31-44

Goya L, Delgado-Andrade C, Rufian-Henares JA, Bravo L, Morales FJ (2007) Effect of coffee melanoidin on human hepatoma HepG2 cells. Protection against oxidative stress induced by tertbutylhydroperoxide. Mol Nutr Food Res 51:536-545

Hofmann T, Schieberle P (2002) Chemical interactions between odor-active thiols and melanoidins involved in the aroma staling of coffee beverages. J Agric Food Chem 50: 319-326

Kang JS, Seo JY, Cho KM, Lee CK, Kim JH, Kim JS (2016) Antioxidant and neuroprotective effects of doenjang prepared with Rhizopus, Pichia, and Bacillus. Prev Nutr Food Sci 21: 221-226

Katsube T, Tabata H, Ohta Y, Yamasaki Y, Anuurad E, Shiwaku K, Yamane Y (2004) Screening for antioxidant activity in edible plant products: comparison of low-density lipoprotein oxidation assay, DPPH radical scavenging assay, and Folin-Ciocalteu assay. J Agric Food Chem 52: 2391-2396

Klatsky AL, Monton C, Udaltsova N, Friedman D (2006) Coffee, cirrhosis, and transaminase enzymes. Arch Intern Med 166: 1190-1195

Korean Ministry of Food and Drug Safety (2017) Korean Food Standards Codex, Ministry of Food and Safety, Cheongju

Kuhnen S, Moacyr JR, Mayer JK, Navarro BB, Trevisan R, Honorato LA, Maraschin M, Pinheiro Machado Filho LC (2014) Phenolic content and 
ferric reducing-antioxidant power of cow's milk produced in different pasture-based production systems in southern Brazil. J Sci Food Agric 94: $3110-3117$

Kumazawa K, Masuda H (2003) Identification of odor-active 3-mercapto-3methylbutyl acetate in volatile fraction of roasted coffee brew isolated by steam distillation under reduced pressure. J Agric Food Chem 51: 3079_ 3082

Martin MA, Ramos S, Mateos R, Rufian-Henares JA, Morales FJ, Bravo L, Goya L (2009) Biscuit melanoidins of different molecular masses protect human HepG2 cells against oxidative stress. J Agric Food Chem 57:7250-7258

Moon JK, Yoo H, Shibamoto T (2009) Role of roasting conditions in the level of chlorogenic acid content in coffee beans: Correlation with coffee acidity. J Agric Food Chem 57: 5365-5369

Nichenametla SN, Taruscio TG, Barney DL, Exon JH (2006) A review of the effects and mechanisms of polyphenolics in cancer. Crit Rev Food Sci Nutr 46: 161-183

Oh J-G, Chun S-H, Kim DH, Kim JH, Shin HS, Cho YS, Kim YK, Choi H, Lee K-W (2017) Anti-inflammatory effect of sugar-amino acid Maillard reaction products on intestinal inflammation model in vitro and in vivo. Carbohydrate Res 449: 47-58

Papetti A, Daglia M, Aceti C, Quaglia M, Gregotti C, Gazzani G (2006) Isolation of an in vitro and ex vivo antiradical melanoidin from roasted barley. J Agric Food Chem 54: 1209-1216

Perrone D, Farah A, Donangelo CM, de Paulis T, Martin PR (2008) Comprehensive analysis of major and minor chlorogenic acids and lactones in economically relevant Brazilian coffee cultivars. Food Chem 106: 859-867

Re R, Pellegrini N, Proteggente A, Pannala A, Yang M, Rice-Evans C (1999) Antioxidant activity applying an improved ABTS radical cation decolorization assay. Free Radic Biol Med 26: 1231-1237

Samaras TS, Gordon MH, Ames JM (2005) Antioxidant properties of malt model systems. J Agric Food Chem 53: 4938-4945

Sauer T, Raithel M, Kressel J, Münch G, Pischetsrieder M (2013) Activation of the transcription factor Nrf2 in macrophages, Caco-2 cells and intact human gut tissue by Maillard reaction products and coffee. Amino Acids 44: $1427-1439$

Shimoda H, Seki E, Aitani M (2006) Inhibitory effect of green coffee bean extract on fat accumulation and body weight gain in mice. BMC Comp Alt Med 6: 9

Smith JP, Daifas DP, El-Khoury W, Koukoutsis J, El-Khoury A (2004) Shelf life and safety concerns of bakery products: A review. Crit Rev Food Sci Nutr 44: 19-55

Speer K, Kölling-Speer I (2006) The lipid fraction of the coffee bean. Braz J Plant Physiol 18: 201-216

Stelmach E, Pohl P, Szymczycha-Madeja A (2015) The content of $\mathrm{Ca}, \mathrm{Cu}, \mathrm{Fe}$, $\mathrm{Mg}$ and $\mathrm{Mn}$ and antioxidant activity of green coffee brews. Food Chem 182: $302-308$

Toci AT, Neto V, Torres AG, Farah A (2013) Changes in triacylglycerols and free fatty acids composition during storage of roasted coffee. Food Sci Technol 50: 581-590

van Boekel M, Fogliano V, Pellegrini N, Stanton C, Scholz G, Lalljie S, Somoza V, Knorr D, Jasti PR, Eisenbrand G (2010) A review on the beneficial aspects of food processing. Mol Nutr Food Res 54: 1215-1247

Vila MA, Andueza S, de Peña MP, Concepción C (2005) Fatty acid evolution during the storage of ground, roasted coffees. J Am Oil Chem Soc 82: 639-646

Wang Y, Ho C-T (2009) Polyphenolic chemistry of tea and coffee: A century of progress. J Agric Food Chem 57: 8109-8114

Watanabe T, Arai Y, Mitsui Y, Kusaura T, Okawa W, Kajihara Y, Saito I (2006) The blood pressure-lowering effect and safety of chlorogenic acid from green coffee bean extract in essential hypertension. Clin Exp Hyperten 28: 439-449

Woo Y, Oh J, Kim JS (2017) Suppression of Nrf2 activity by chestnut leaf extract increases chemosensitivity of breast cancer stem cells to Paclitaxel. Nutrients 9: 760

Xue M, Qian Q, Adaikalakoteswari A, Rabbani N, Babaei-Jadidi R, Thornalley PJ (2008) Activation of NF-E2-related factor-2 reverses biochemical dysfunction of endothelial cells induced by hyperglycemia linked to vascular disease. Diabetes 57: 2809-2817 